\title{
VLOGA MENTORJA V IZOBRAŽEVANJU STAREJŠIH ODRASLIH IN RAZVOJ MENTORSKEGA ODNOSA
}

Doc. dr. Monika Govekar-Okoliš

Dr. Renata

Kranjěec

Filozofska fakulteta

Univerze $v$ Ljubljani

\section{POVZETEK}

Prispevek prinaša spoznanja o pomenu mentorja in njegovi vlogi v izobraževanju starejših odraslih. Starejši odrasli so lahko udeleženci izobraževanja oz. mentoriranci v mentorskem procesu, lahko pa tudi mentorji drugim osebam, ne glede na starost. Pomembno je, da imajo poleg svojih strokovnih znanj in izkušenj tudi nekatera znanja o vlogi mentorja, pomenu komunikacije in mentorstvu kot procesu. Omenjeno bomo predstavili v prispevku, kjer bomo še posebej poudarili skupne značilnosti mentorstev na različnih področjih. Predvsem je za razvoj mentorskega odnosa pomembna na posameznika usmerjena paradigma mentorstva. Poleg te pa bomo opisali tudi razvojne stopnje v mentorskem odnosu, ki so pomembne za dosego dobrega mentorstva starejšim odraslim osebam.

Ključne besede: starejši odrasli, mentor, vloge mentorja, komunikacija, značilnosti mentorstva, paradigma mentorstva, razvojne stopnje v mentorskem odnosu

\section{THE ROLE OF THE MENTOR IN THE EDUCATION OF OLDER ADULTS AND MENTORSHIP DEVELOPMENT - ABSTRACT}

The article deals with the importance of the mentor and his role in the education of older adults. Older adults may be not only participants in education, or mentees in mentoring processes, but also mentors to other persons, irrespective of age. It is important that in addition to their specific knowledge and experiences they possess some knowledge of the mentor's role, of the role of communication and mentoring as a process. These aspects are presented in the article, focusing especially on the common characteristics of mentoring in different areas. The mentee-centered mentoring paradigm is presented as vital for the development of a mentoring relationship. Along with it, the article describes the developmental phases of a mentoring relationship that contribute to the achievement of a good mentorship relationship in the education of older adults.

Keywords: older adults, mentor, mentor's roles, communication, mentorship, mentee- centered mentoring paradigm, developmental phases in a mentoring relationship

UDK: 374.7

Življenje starejših odraslih v družbi, kjer lahko nadaljujejo učenje novih vrednot in stališč, pridobivanje novih znanj, ozaveščanje o svojem položaju in svoji možnosti nadaljnjega aktivnega delovanja v družbi, jim omogoča izobraževanje ter vključevanje $\mathrm{v}$ različne institucije in društva. Tu mislimo zlasti na doslej dobro organizirane oblike delovanja Društva za izobraževanje za tretje življenjsko obdobje, ki ima v Sloveniji začetke že v letu 1984 na Univerzi za tretje življenjsko obdobje v Ljubljani. Omenjeno delovanje se širi v več krajev po Sloveniji in omogoča starejšim odraslim, da se vključujejo v različne študijske krožke in dejavnosti. S tem se lahko nadaljnje osebnostno razvijajo in pridobivajo nove družbene moči.

Za starejše odrasle ljudi je značilno, da imajo željo, da bi postali nekaj, kar prej niso bili, da bi dali svoji osebnosti nove razsežnosti. Mnogi med njimi bi radi pridobili znanja, ki so si jih v življenju želeli imeti, pa jih zaradi službenih, družinskih ter drugih obveznosti 
in razlogov niso mogli pridobiti. Želijo si novih znanj, ki jih v času svojega šolanja in službovanja niso mogli usvojiti, ker jih ni bilo. Taka znanja danes zahteva nov način življenja in komunikacije (npr. uporaba računalnika). Da bi se nadalje osebnostno izpopolnjevali, imajo starejši odrasli možnost, da se vključijo v izobraževanje. Med drugim se lahko njihova dejavnost širi na področja medsebojnega sodelovanja in izobraževanja, starejši s starejšimi ali starejši z mlajšimi, kjer gre za medgeneracijsko sodelovanje in izobraževanje. Pomembno je, da tudi starejši odrasli pridobijo znanja za delo, izobraževanje in mentorstvo drugim osebam in se pri tem osebnostno izpopolnjujejo. Pri tem ni več vprašanje, ali je lahko starejša odrasla oseba tudi mentor drugim mlajšim, odraslim ali starejšim odraslim. Gre za spoznanje, da so prav starejši odrasli lahko dobri mentorji, ker imajo veliko znanja, življenjskih izkušenj, in če imajo voljo za mentorstvo drugim, jih je treba spodbuditi in podpreti. Zato, da so in bodo dobri mentorji, pa potrebujejo tudi znanja, ki razkrivajo posebnosti dela mentorja. Ne glede na starost mentorja so pomembni njegova strokovnost, znanje o tem, kdo je mentor, kakšne so njegove vloge in kaj je treba znati, da bo mentorstvo dobro in posamezniki mentoriranci zadovoljni.

Danes lahko najdemo veliko število opredelitev, kdo je mentor in kakšne so njegove značilnosti ter vloge. Avtorji, denimo Kejžar (1986), Daloz (1986) ter Zupan-Kušče (1989) in drugi, so konec osemdesetih let 20. stoletja opredelili mentorja kot vodnika, kot spodbujevalca in kot tistega, ki ima dovolj izkušenj. V devetdesetih letih 20. stoletja Clutterbuck (1994) in angleški andragog Jarvis (1995) predstavita širšo opredelitev mentorja. Mentor, kot menita, ima znanja in izkušnje o nekem strokovnem področju, pozna sposobnosti mentoriranca in ga lahko vodi. Shea (v Parsloe in Wray, 2000) pravi, da je mentor oseba, ki skozi svoja dejanja in delo pomaga drugemu pri uresničevanju njegovih možnosti. Gibb (2006) pa imenuje mentorja »izvršitelj «, ki ima osebni interes pomagati voditi in razvijati manj izkušeno osebo.

Opredelitve o tem, kdo je mentor, nam kažejo, da mora imeti mentor določene osebnostne lastnosti, sposobnosti, da je lahko opora mentorirancu $\mathrm{v}$ njegovem strokovnem in osebnostnem razvoju. Še posebno pa je pomembno, da se mentor, ki mentorira starejše osebe, zaveda in pozna posebnosti dela pri izobraževanju starejših odraslih ljudi.

\section{VLOGE MENTORJA V IZOBRAŽEVANJU STAREJŠIH ODRASLIH}

Ključne vloge mentorja v izobraževanju starejših odraslih bomo poskušali prikazati na podlagi razlag nekaterih avtorjev, ki raziskujejo proces mentorstva. Mentor je lahko v vlogi vzornika, motivatorja in svetovalca (Opalk, 2003). Pri oblikovanju vloge mentorja sta pomembna dva tipa mentorjev:

- mentorji, ki delujejo usmerjevalno in po vnaprej določeni poti in shemi učnih epizod sistematično vodijo do znanja;

- mentorji, ki so neusmerjevalni, delujejo bolj sproščeno, odprto in poskušajo vključiti v proces učenja tisto, kar pri posamezniku sproti odkrivajo.

Najboljši mentorji so tisti, ki imajo vnaprej začrtano pot in shemo poučevanja, hkrati pa so se pripravljeni prilagajati sprotnim odkritjem glede potreb osebe, in če je treba, kakšno metodo ali način dela spremenijo (Krajnc, 1984). 


\section{Vloga mentorja kot vodje}

Tudi vloge mentorjev so med avtorji različno opredeljene. Glasser (1994), denimo, postavlja v ospredje vlogo mentorja kot vodje, ki mentorirance vodi na način, da ti vidijo povezavo med tem, kar delajo, in tem, $\mathrm{v}$ kar verjamejo, da je kakovost. Nastran-Ule (1994) navaja, da je najpomembnejša vloga mentorja prav vloga vodje. Lahko govorimo o treh vrstah nalog mentorjev kot vodij. Prve, psihološke naloge mentorja razkrivajo, da je mentor kot vodja lahko psihološka opora, identifikacijska »figura«, simbol skupine, ki daje posameznikom občutek varnosti, samozaupanja in potrditve. Druge, socialne naloge mentorja narekujejo, da je mentor kot vodja tisti, ki organizira in koordinira delitev dela med posamezniki v skupini. Je razsodnik v konfliktnih situacijah znotraj skupine. Predstavlja tudi skupino posameznikov navzven. Tretja, strokovna naloga mentorja kot vodje je, da je koordinator aktivnosti, načrtovalec in dober strokovnjak (Nastran-Ule, 1994). Secord in Backman (v Nastran-Ule, 1994) utemeljujeta, da je mentor vodja tisti, ki ga vodeni vidijo kot vodjo in ga sprejmejo ter podpirajo. Biti mentor vodja pomeni biti oseba, ki ima strokovna znanja in zna voditi, motivirati in dajati oporo posameznikom mentorirancem.

\section{Vloga mentorja kot svetovalca}

Ena pomembnejših vlog mentorja je, da je svetovalec. Zato je pomembno, da mentor ve, kaj pomeni svetovanje, in da ga zna tudi izvajati v praksi. »Svetovanje je organizirana oblika pomoči posamezniku pri njegovem nadaljnjem napredku, osebni rasti in razvoju.« (Kristančič, 1995: 10.) Če želi mentor v procesu svetovanja razumeti posameznikove potrebe, mora poznati najprej svoje lastne vzgibe in potrebe. Le tako ve, kaj bo delal in kaj želi doseči v mentorskem odnosu.
Kristančič in Ostrman (1998) navajata tri področja, ki sovplivajo na vzpostavljanje dobrega svetovalnega odnosa:

- vrste in načini komuniciranja mentorja svetovalca,

- čustvovanje mentorja svetovalca,

- mišljenje mentorja svetovalca.

Mentor mora znati uporabljati notranji govor in biti sposoben sprejemati realne odločitve. Pomembno je, da razume svoje misli in čustvene odzive.

Mentor mora upoštevati, da je pogoj za uspešno mentorstvo v izobraževanju starejših odraslih partnerski odnos. Partnerstvo mora temeljiti na zaupanju, medsebojni pomoči in odgovornosti vseh ude-

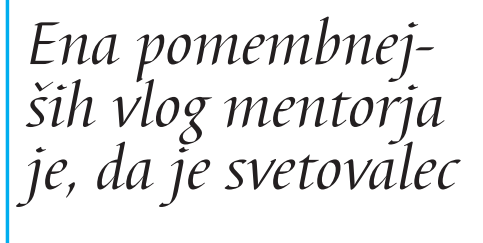
ležencev v mentorskem odnosu. S tem se odpira večja možnost sodelovanja med različno starimi v skupinah in lahko razvijamo medgeneracijsko sodelovanje. Prav tako mora mentor vedeti, da sta pogoj za kakovostno mentorstvo ustrezno strokovno znanje in izobraženost s področja svetovanja. Mentor svetovalec mora poznati znanja, sposobnosti, motivacijo idr. starejših odraslih, predvsem pa cilj, da znajo povezati že obstoječa teoretična in praktična znanja $\mathrm{v}$ samem procesu izobraževanja ter se pri tem osebno in strokovno izpopolniti.

Imeti znanja o mentorju kot vodji in svetovalcu pa ni dovolj za kakovostno mentorstvo. Prav gotovo je za dosego tega pomembno tudi obvladovanje ustrezne komunikacije, saj dejansko ta omogoča uresničevanje mentorjeve vloge kot vodje in kot svetovalca, hkrati pa razvija medosebni odnos med mentorjem in posameznim mentorirancem - starejšo odraslo osebo. 


\section{KOMUNIKACIJA MED MENTORJEM IN STAREJŠO ODRASLO OSEBO}

Preden začnemo govoriti o komunikaciji med mentorjem in starejšo odraslo osebo, naj poudarimo, da je komunikacija dejavnost osrednjega pomena, je vsesplošen pojav, ki sestavlja neizogiben del našega vsakdanjika. Človek, ne glede na starost, je že po naravi družbeno bitje in prav s tem, ko komunicira, uravnava in vzdržuje socialne odnose ter svoje notranje ravnotežje skozi vse življenje. To seveda velja tudi za komunikacijo v izobraževanju starejših odraslih. Opredelitev komunikacije je veliko. Ponazorili jo bomo s štirih vidikov (Littlejohn, 1992):

- $\quad \mathrm{z}$ vidika procesa, kjer se komunikacija razume kot prenos informacij, idej in čustev z uporabo simbolov;

- $\quad \mathrm{z}$ vidika sporazumevanja, kjer je komunikacija dinamičen proces, ki se nenehno spreminja in prek katerega se medsebojno sporazumevamo;

- $\quad \mathrm{z}$ vidika povezovanja, kjer je komunikacija razumljena kot proces, s katerim se med seboj povezujejo različni deli živega sveta;

- $\quad \mathrm{z}$ vidika pridobivanja moči, kjer komunikacijo razumemo kot mehanizem, s pomočjo katerega se uveljavlja moč.

Komunikacija je proces pošiljanja in sprejemanja sporočil, ki je sogovorniku razumljiv. S komunikacijo vplivamo na drugo osebo ali jo celo spreminjamo (Lamovec, 1993).

\section{Vrste mentorjev glede na način komuniciranja}

Mentorji morajo vedeti, kakšna je lahko komunikacija med mentorjem in starejšo odraslo osebo $\mathrm{v}$ mentorskem procesu.
Glede na način komuniciranja ločimo različne vrste mentorjev. Najboljši mentorji glede na način komuniciranja so (prirejeno po Brajša, 1983):

- dorečeni mentorji so konkretni, dodelani, preverjajo svoje domneve in so redkeje napačno razumljeni. Z njimi je laže sodelovati, ker imajo dorečena sporočila;

- jaz mentorji uporabljajo jaz sporočila, povejo jasno in neposredno svoje mnenje, opažanja in razlage. Govorijo iz sebe, s svojo osebnostjo se obrnejo k osebnosti mentoriranca, saj imajo le tako lahko pravi osebni stik s človekom;

- razumljivi mentorji govorijo preprosto, pregledno, strnjeno in zanimivo. $\mathrm{Nji-}$ hova sporočila so prepoznavna in konkretno uporabna, $\mathrm{z}$ malo besed podajajo bistvo. Taki mentorji nimajo problema $\mathrm{z}$ vodenjem. Razumljivost je prvi pogoj sporočila;

- objektivni mentorji ne vpletajo svojih opažanj, mnenj in čustev. Njihova komunikacija $\mathrm{z}$ mentoriranci je objektivna in pravična;

- jasni mentorji so sebi in mentorirancem jasni, imajo jasen uvid v sebe, svoje vedenje in komuniciranje, vedo, kaj govorijo, in z mentoriranci razvijejo resničen, pravi dialog. Kot mentorji so uspešni in prepričljivi;

- $\quad$ posredni mentorji dopuščajo, da mentoriranci izrazijo svoja čustva.

Poznavanje najboljših vrst mentorjev glede na način komuniciranja je pomembno zato, da mentorji lahko izboljšajo svojo komunikacijo $\mathrm{v}$ mentorskem odnosu.

\section{Povratno informiranje}

Pomemben del komunikacije $\mathrm{v}$ mentorskem odnosu med mentorjem in starejšo odraslo osebo je tudi povratno informiranje. Povratno 
informiranje potrebuje tako starejša odrasla oseba, da bo vedela, kako opravlja svoje delo, kako se izobražuje, osebno napreduje, kot tudi mentor. Seveda pa je vprašanje, kako mentor starejši osebi posreduje povratno informacijo ali »komunikacijski feedback «. »To je povratna informacija o sebi in svoji komunikaciji, o drugem in njegovi komunikaciji, o nas in naši medsebojni komunikaciji, ki jo kot sobesedniki ponujamo $\mathrm{v}$ medsebojnem komuniciranju.« (Brajša, 1993: 77.) Povratno informiranje je lahko sprotno, lahko pa je tudi končno, na koncu izobraževanja oz. mentorstva starejšim odraslim osebam. Mentor mora starejši odrasli osebi posredovati tako pozitivne kot negativne informacije o njenem delu med izobraževanjem. »Če so negativne povratne informacije posredovane pravilno, so lahko učinkovit mehanizem vodenja!« (Opalk, 2003: 18.)

Za mentorja je pomembno, da vsako povratno informacijo prilagodi posamezniku, njegovim zmožnostim razumevanja in možnostim spreminjanja. Pri tem naj upošteva tudi čas in kraj iskanja in sprejemanja informacij, saj če povratnih informacij ne prilagodi posamezni starejši odrasli osebi, potem lahko te delujejo negativno. Zato je za mentorja zelo pomembno, da starejši odrasli osebi daje povratno informacijo pravočasno, kajti znano je, da mentorji radi dajejo poznejše, dodatne povratne informacije, zlasti negativne. Prav tako naj mentor starejši odrasli osebi povratne informacije ponudi, nikakor pa naj ji jih ne vsiljuje. Starejša odrasla oseba bo sprejela ponujena in ne vsiljena sporočila.

Mentorji, ki poznajo pomen komunikacije $\mathrm{v}$ mentorstvu, njene oblike in pomen povratnega informiranja (sprotnega in končnega), imajo veliko več možnosti, da vzpostavijo dobre mentorske odnose in so bolj zadovoljni v mentorstvu.

\section{SKUPNE ZNAČILNOSTI MENTORSTEV NA RAZLIČNIH PODROČIIH}

Vsako mentorstvo je drugačno. To velja tudi za mentorstvo starejšim odraslim osebam. O tem, kaj sploh je mentorstvo, najdemo različne opredelitve, npr. Krajnc (1979), Daloz (1986), Clutterbuck (1994), Galbraith in Cohen (1995) idr. pravijo, da je toliko oblik mentorskega dela, kolikor je mentorjev. Vendarle pa obstajajo tudi nekatere skupne značilnosti. To lahko potrdimo na podlagi primerjalne raziskave mentorstva na različnih področjih (npr. študijskem, delovnem, zasebnem), ki pokaže številne podobnosti (Allen in Eby, 2007). Eby, Rhodes in Allen (2007) navajajo naslednje skupne značilnosti mentorstva:

- Mentorstvo je edinstven odnos med posameznikoma. Ni dveh enakih mentorskih odnosov, saj gre za različno medosebno izmenjavo. Značilni vzorci interakcije opredeljujejo in oblikujejo odnos. Mentorski odnosi so lahko taki, da spremenijo posameznikovo življenje, lahko so površinski ali pa celo destruktivni.

- Mentorstvo je učno partnerstvo. Čeprav so cilji mentorskih odnosov lahko različni, skoraj vsi vključujejo pridobivanje znanja. Učenje lahko poteka $\mathrm{v}$ zelo učinkovitih mentorstvih kot tudi v mentorskih odnosih, ki jih eden ali oba izkusita kot spodletele.

- Mentorstvo je proces, ki ga opredeljuje način opore mentorja kandidatu. Čeprav so specifične funkcije, ki označujejo mentorstva, različne, je v splošnem sprejeta delitev na strokovne ali inštrumentalne (npr. informiranje, izpostavljanje mentoriranca) in psihosocialne ali čustvene (npr. prijateljstvo z mentorirancem, sprejetost mentoriranca).

- Mentorski odnos je vzajemen, vendar še vedno asimetričen. Čeprav ima tudi 
mentor koristi od mentorskega odnosa, je primarni cilj rast in razvoj mentoriranca.

- Mentorski odnos je dinamičen in se spreminja skozi čas. Vpliv mentorstva sčasoma narašča.

\section{NA POSAMEZNIKA USMERJENA PARADIGMA MENTORSTVA}

Pri izobraževanju starejših odraslih nič več ne prevladuje paradigma mentorstva kot hierarhičnega prenosa znanja in informacij od mentorja kot bolj izkušene osebe na mentoriranca kot manj izkušenega. Praksa mentorstva starejšim odraslim se premika od modela, za katerega je značilen prenos znanja, k procesno usmerjenemu odnosu, ki vključuje pridobivanje znanja, njegovo uporabo in kritičen premislek. Mentoriranec ima v učenju dejavnejšo vlogo kot $\mathrm{v}$ prejšnji bolj tradicionalni paradigmi od mentorja odvisnega mentoriranca, ki sledi navodilom mentorja in od njega sprejema znanje. Fraza »partnerstvo $\mathrm{v}$ učenju « je skladna $\mathrm{z}$ mentorsko paradigmo usmerjenosti na mentoriranca, ki temelji na znanju o učenju starejših odraslih. Danes na mentorstvo ne gledamo več kot na pretok modrosti od mentorja $\mathrm{k}$ mentorirancu, ampak se odkriva v učnem odnosu, v katerem oba poskušata pridobiti boljše razumevanje področja mentoriranja in sveta. Mentor ima bolj spodbujevalno vlogo. Mentoriranec se uči prevzemati del odgovornosti za učno okolje, prioritete, učenje in vire ter postaja vse bolj samousmerjevalen. Kadar mentoriranec ni pripravljen na prevzem te stopnje odgovornosti, naj mentor razvija njegovo zmožnost za samousmerjanje (od odvisnosti $\mathrm{k}$ neodvisnosti do medsebojne odvisnosti) med graditvijo odnosa. $\mathrm{V}$ razvoju učnega odnosa oba partnerja $\mathrm{v}$ mentorskem odnosu skupaj nosita odgovornost za doseganje učnih ciljev.

Tabela 1: Elementi na mentoriranca usmerjene paradigme (prilagojeno po Zachary, 2000)

\begin{tabular}{|c|c|c|}
\hline Elementi mentorstva & Sprememba v paradigmi & Načelo učenja odraslih \\
\hline Vloga mentoriranca & $\begin{array}{l}\text { Od nedejavnega prejemnika } \mathrm{k} \\
\text { dejavnemu partnerju }\end{array}$ & $\begin{array}{l}\text { Odrasli se najbolje učijo, kadar so vpleteni } \\
\text { v diagnosticiranje, načrtovanje, izvajanje in } \\
\text { ovrednotenje svojega lastnega učenja. }\end{array}$ \\
\hline Vloga mentorja & Od avtoritete k spodbujevalcu & $\begin{array}{l}\text { Vloga spodbujevalca je, da ustvari in } \\
\text { ohranja oporno vzdušje, ki spodbuja } \\
\text { pogoje, nujne za učenje. }\end{array}$ \\
\hline Učni proces & $\begin{array}{l}\text { Od mentorjevega usmerjanja in njegove } \\
\text { odgovornosti za učenje mentoriranca k } \\
\text { samousmerjanju in lastni odgovornosti } \\
\text { mentoriranca za svoje učenje }\end{array}$ & Odrasli imajo potrebo po samousmerjanju. \\
\hline Trajanje odnosa & $\begin{array}{l}\text { Od osredotočanja na koledar k } \\
\text { določanju ciljev }\end{array}$ & $\begin{array}{l}\text { Pripravljenost na učenje narašča, kadar } \\
\text { obstaja specifična potreba po vedeti. }\end{array}$ \\
\hline Mentorski odnos & $\begin{array}{l}\text { Od enega mentorja v življenju k več } \\
\text { mentorjem in več mentorskim modelom; } \\
\text { individualni, skupinski in drugi modeli }\end{array}$ & $\begin{array}{l}\text { Življenjski zbir izkušeni je glavni učni vir; } \\
\text { življenjske izkušnje drugih obogatijo učni } \\
\text { proces. }\end{array}$ \\
\hline Okolje & $\begin{array}{l}\text { Od neposredne komunikacije } k \text { več in } \\
\text { različnim okoljem in možnostim }\end{array}$ & $\begin{array}{l}\text { Odrasli imajo sebi lastno potrebo za } \\
\text { takojšnjost uporabe. }\end{array}$ \\
\hline Osredotočenost & $\begin{array}{l}\text { Od usmerjenosti na prenos in } \\
\text { pridobivanje znanja k usmerjenosti na } \\
\text { proces: kritični premislek in uporaba }\end{array}$ & $\begin{array}{l}\text { Odrasli se na učenje najbolj odzivajo, } \\
\text { kadar so notranje motivirani zanj. }\end{array}$ \\
\hline
\end{tabular}


V Tabeli 1 so prikazani temeljni elementi na mentoriranca usmerjene paradigme mentorstva, ki so prilagojeni po Zacharyjevih (2000) ugotovitvah o izobraževanju odraslih.

\section{RAZVOINE STOPNJE V MENTORSKEM ODNOSU}

Kramova (Galbraith in Maslin-Ostrowski, 2000, ter Russell, 2004) je raziskovala stopnje mentorskega odnosa in odkrila, da se mentorski odnos značilno razvija skozi štiri napovedljive razvojne stopnje.

\section{Vzpostavitev odnosa}

Skozi prvo obdobje se začne odnos vzpostavljati in oba, mentor in mentoriranec, opazita, da nastaja mentorski odnos. Mentor skrbi za strokovni razvoj mentoriranca (npr. inštruiranje oz. treniranje, skrb za opaznost mentoriranca) in daje nekaj psihosocialne podpore (npr. oblikovanje vloge). Oba občutita značilno vznemirjenje in izziv, ko začneta delati skupaj. Mentoriranec občuti, da ga nekdo podpira, in mentor občuti, da je prevzel skrb za razvoj in inštruiranje nekoga.

\section{Vzdrževanje odnosa}

Skozi naslednje obdobje se strokovna in psihosocialna funkcija stopnjujeta. Pozitivna pričakovanja, ki so nastala na stopnji vzpostavitve odnosa, mentor in mentoriranec preizkušata v realnosti. Spoznavata vrednost medsebojnega odnosa in njegove meje. Oba, mentor in mentoriranec, pridobivata $\mathrm{z}$ odnosom in razvijeta močno vez. Seveda pa se vsi mentorski pari ne razvijajo na čisto enak način. Razvoj odnosa je odvisen od potreb in interesov tako mentorja kot mentoriranca. V splošnem vidita oba partnerja to obdobje v pozitivni luči.

\section{Ločitev}

Po prejšnjem obdobju vzdrževanja odnosa nastopijo spremembe. Značilno je, da mentoriranec postane bolj neodvisen oz. manj odvisen od mentorjeve strokovne podpore. $\mathrm{V}$ fazi ločevanja se lahko pojavijo občutki žalosti, tesnobe, izgube in zmede, ker se odnos končuje oz. spreminja.

\section{Ponovna opredelitev odnosa}

Po stopnji ločevanja se odnos lahko konča ali pa se spremeni. Postane lahko prijateljski ali pa ga zaznamujejo zamere. Mentoriranec in mentor lahko, denimo, postaneta bolj podobna kolegoma na isti ravni in redefinirata svoj odnos v prijateljstvo. Lahko se pojavi tudi ambivalentnost in neugodje, ker sta spremenila odnos. Sočasno lahko mentoriranec občuti veliko samozaupanje in avtonomijo pri nadaljnjem uveljavljanju. Na splošno skozi stopnjo ponovne opredelitve odnosa mentor in mentoriranec spoznata, da je prišlo do spremembe položaja in da prejšnji mentorski odnos ni več potreben.

Ko mentor in mentoriranec izstopita iz mentorskega odnosa, lahko oba odneseta bolj ali manj dobre izkušnje. Čeprav razvoja opisanih stopenj ne izkusijo vsi enako, je bistveno, da praviloma vsi preidejo opisane faze, in to $\mathrm{v}$ enakem zaporedju.

Poznamo pa tudi drugačen model stopenjskega razvoja mentorstva (Zachary, 2002). Štiri predvidljive stopnje, skozi katere napreduje mentorski odnos, so: priprava, dogovarjanje, usposabljanje in doseganje zaključka. Te stopnje temeljijo druga na drugi in skupaj oblikujejo razvojno zaporedje, katerega dolžina se spreminja od odnosa do odnosa (Slika 1). Od prej opisanega modela Kramove se ta razlikuje po tem, da se stopnje bolj osredotočajo 
na vedenja, potrebna za premik z ene na drugo stopnjo. Čeprav so stopnje predvidljive in zaporedne, niso vedno ločene. Zavedanje o pomenu vsake od stopenj pomaga ohranjati uspešen mentorski odnos, tako formalni kot neformalni. Če vzamemo stopnje za same po sebi zagotovljene ali katero od njih izpustimo, ima to lahko negativne posledice.

\section{Priprava}

Vsak mentorski odnos je edinstven. Zato se morata mentor in mentoriranec vsakič, ko se začne

Slika 1: Stopnje mentorskega odnosa (Zachary, 2002)

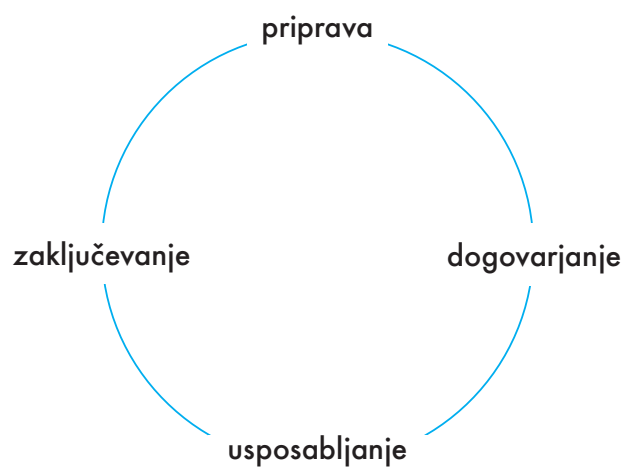

nov mentorski odnos, pripraviti individualno in v partnerstvu. Mentorstvo je več kot srečanje pravega mentorja; mentor mora srečati tudi pravega mentoriranca. Doseči pravo ujemanje zahteva pripravo sebe in mentorskega odnosa. Mentorski programi navadno ponujajo neko pomoč in usposabljanje pred prevzemanjem te vloge. Ker je vsak mentorski odnos edinstven, je treba najprej premisliti o zadevi in se pripraviti. Vzeti si čas za pripravo, za odnos, ustvarja plodna tla za mentorski odnos in dodaja vrednost mentorskemu partnerstvu. Med pripravo poteka več procesov.

Lastna priprava. Na stopnji priprave mentorskega odnosa sočasno poteka več procesov. Mentor raziskuje osebno motivacijo in pripra- vljenost za prevzem mentorstva. Individualna ocena svoje mentorske spretnosti mu pomaga prepoznati področja za svoje učenje in razvoj. Jasnost glede pričakovanj in vloge pomaga pri opredeljevanju parametrov za vzpostavljanje učinkovitega in zdravega mentorskega odnosa.

Priprava odnosa. Okoliščine oblikovanja mentorskega odnosa se spreminjajo. Mentorju je lahko mentoriranec določen, ali mentor mentoriranje nekomu ponudi sam, ali pa mentorja izbere mentoriranec. Začetni pogovor, v katerem potencialni mentorski partnerji raziščejo vzajemnost interesov, učnih potreb in določijo učno ujemanje, je odločilen. Rezultati tega pogovora pomagajo mentorju pri oceni, ali bo lahko učinkovito delal s predvidenim mentorirancem.

\section{Dogovarjanje}

$\mathrm{Na}$ tej stopnji partnerja $\mathrm{v}$ mentorskem odnosu dosežeta dogovor o učnih ciljih ter opredelita vsebino in proces odnosa. Ključni del je pogovor, ki vodi do dogovora. Pri tem gre bolj za ustvarjanje vzajemnega razumevanja glede domnev, pričakovanj, ciljev in potreb kot pa za oblikovanje formalnega dogovora. Vključuje tudi pogovor o nekaterih zadevah $\mathrm{v}$ odnosu, kot so zaupnost, meje in omejitve, ki se pogosto izpustijo iz mentorskih pogovorov, saj se je partnerjem o tem običajno težko pogovarjati. Tak pogovor daje dobro podlago za gradnjo zaupanja. $\mathrm{V}$ pogovorih se opredelijo specifične podrobnosti odnosa, kot so: kdaj in kako se bosta srečevala, odgovornosti, merila uspeha in kako zaključiti odnos. Pogosto obstaja težnja po izpuščanju te stopnje odnosa, zlasti pri mentorjih.

\section{Usposabljanje}

Ta stopnja traja dlje od prejšnjih, saj gre za uresničevanje učnega odnosa in se v okviru te 
faze dogaja večina stikov mentorskega para. Čeprav ponuja največje možnosti za učenje in razvoj, je to obodobje tudi najbolj občutljivo za ovire, ki lahko razdrejo odnos.

Vsak mentorski odnos je namreč edinstven in se mora razvijati po svoji lastni poti. Čeprav so cilji jasno oblikovani, proces dobro opredeljen in mejniki določeni, mora vsak odnos najti svojo lastno pot. Stopnja usposabljanja je proces gradnje poti: ohranjanje zadostne stopnje zaupanja za razvoj kakovosti mentorskega odnosa in spodbujanje učenja. Učinkovita komunikacija je ključna. Učenje, ki poteka na stopnji izobraževanja oziroma usposabljanja, je torej odvisno od ohranjanja vzdušja vzajemnega zaupanja in spoštovanja.

Mentorjeva vloga na tej stopnji je skrb za rast mentoriranca $\mathrm{z}$ vzdrževanjem odprtega in potrjevalnega vzdušja, postavljanjem pravih vprašanj ob pravem času in nudenjem skrbne, pravočasne, iskrene in konstruktivne povratne informacije. Tako mentor kot mentoriranec morata nadzirati učni napredek in učni proces, da bi dosegla učne cilje. Učni mejniki morajo biti opaženi in proslavljeni.

\section{Zaključevanje}

Zaključevanje je razvojni proces, ki se dejansko začne na stopnji dogovarjanja, ko partnerja v mentorskem odnosu osnujeta postopek zaključevanja. Med stopnjo izobraževanja oz. usposabljanja se partnerja bolje spoznata, se vse bolj zavedata interesov in potreb drug drugega ter zato lahko bolje skupaj načrtujeta zaključek. Med približevanjem stopnji zaključevanja izvajata svojo izhodno strategijo, ki zagotavlja, da bo učenje zaključeno ne glede na okoliščine. Odnos se lahko začne zelo dobro, z medsebojnim spoštovanjem partnerjev, ujemanjem $\mathrm{v}$ interesih, razvijanjem dobrega stika. Nenadoma pa se lahko pojavi problem.

Ko se to zgodi, mentorji pogosto odkrijejo, da jim pregled dela po stopnjah omogoča oceno in preoblikovanje odnosa $\mathrm{v}$ bolj učinkovitega in vzajemno zadovoljivega. Zavedanje znamenj, ki kažejo, da je čas za konec, omogoča pravočasen in pozitiven zaključek. Stopnja zaključevanja je na videz kratka, vendar daje bogate priložnosti za rast in premislek ne glede na to, ali je bil odnos pozitiven. Zaključevanje je razvojna priložnost za mentorja in mentoriranca, da požanjeta svoje učne uspehe in gresta naprej. Obsega ovrednotenje učenja, priznanje napredka in proslavljanje dosežkov učenja, od njega imajo korist tako mentorji kot mentoriranci. Kadar mentor vidi zaključek kot priložnost za ovrednotenje osebnega učenja in uporabo naučenega $\mathrm{v}$ drugih odnosih in situacijah, pomeni to zanj premik $\mathrm{v}$ lastnem učenju in rasti. Dobra izhodna strategija ima štiri sestavine:

- zaključek učenja (pregled rezultatov učenja in izobraževanja) in proces integracije naučenega,

- način proslave uspeha,

- pogovor, osredotočen na redefiniranje odnosa,

- prijazen način za razhod ali ohranitev stikov.

\section{Vsak mentorski odnos je edinstven}

Pogosto predpostavljamo, da so vsi mentorski odnosi pozitivni oz. visoko kakovostni v vseh razvojnih stopnjah. Novejše raziskave so pokazale, da ni vedno tako (Russell, 2004). Včasih je lahko mentorski odnos tudi disfunkcionalen ali samo zanemarljivo učinkovit.

\section{SKLEPNE MISLI}

Biti mentor, kot smo spoznali, je pomembna vloga. Pomeni biti oseba z znanji in izkušnjami ter motivacijo za vodenje mentorstva, kar je odraz posameznika, ki je spodoben prenašati znanja na druge ljudi in stopati z njimi 
$\mathrm{v}$ dobre medsebojne odnose. $\mathrm{V}$ tem je dober tisti mentor, ki ima tudi znanja o vodenju in svetovanju, kot tudi o pomenu komunikacije $\mathrm{v}$ mentorskem odnosu. Pozna mentorstvo kot proces medsebojnih odnosov, $\mathrm{v}$ katerem je lahko opora starejši odrasli osebi pri razvijanju znanja, spretnosti, sposobnosti in osebnostnih lastnosti. Mentorstvo povečuje človeško zmožnost za oblikovanje povezanosti, razvoj in spreminjanje odraslih skozi življenje. Skozi mentorski odnos se lahko ljudje, ki morda nikoli ne bi imeli priložnosti, učijo drug od drugega in vzpostavijo vzajemno razumevanje in spoštovanje. Mentorstvo je način graditve novih mrež in preseganje posameznikovih ozkih vlog. Talent, ki bi pri posamezniku lahko ostal neopažen, ima tako priložnost, da se izrazi. Ideje, ki bi bile morda izgubljene, se lahko produktivno uporabijo. Najpomembneje pri tem je, da mentorstvo lahko razvije družbo samousmerjajočih se ljudi, ki se vseživljenjsko izobražujejo (Schulz, 1995) in vseživljenjsko učijo, so dejavni, pri tem pa dosegajo želeni osebnostni razvoj, se čutijo del družbe in imajo večje zadovoljstvo tudi v vlogi starejše odrasle osebe.

\section{LITERATURA IN VIRI}

Allen, T. D., Eby, L. T. (2007). »Overview and Introduction«. V Allen, T. D., Eby, L. T. (ur.), The Blackwell handbook of mentoring: a multiple perspective approach. Malden.

Brajša, P. (1983). Vodenje kot medosebni proces. Ljubljana: Univerzum.

Brajša, P. (1993). Pedagoška komunikologija. Ljubljana: Glotta Nova.

Clutterbuck, D. (1994). Everyone needs a mentor: fostering talent at work. London: Institute of Personnel and Development.

Cohen, N. H. (1995). Mentoring adult learners: a guide for educators and trainers. Malabar: Krieger.
Daloz, L. A. (1986). Effective teaching and mentoring: realizing the tranformational power of adult learning experiences. San Francisco: Jossey-Bass.

Eby, L. T., Rhodes, J. E., Allen, T. D. (2007). »Definition and Evolution of Mentoring «. V Allen, T. D., Eby, L. T. (ur.), The Blackwell handbook of mentoring: a multiple perspective approach. Malden.

Galbraith, M. W., Cohen, N. H. (1995). »Issues and Challenges Confronting Mentoring «. V M. W. Galbraith in N. H. Cohen (ur.), Mentoring: New Strategies and Challenges. San Francisco. Galbraith, M. W., Cohen, N. H. (1995). Mentoring: new strategies and challenges. San Francisco: Jossey-Bass.

Galbraith, M. V., Maslin-Ostrowski, P. (2000). Roles of Mentorship. Pridobljeno 15. 1. $2005 \mathrm{~s}$ http://sll. stanford.edu/projects/tomprof/newtomprof/postings/224. html.

Gibb, A. (2006). Mentoring definitions. Pridobljeno 6. $4.2006 \mathrm{~s}$

http://www.andrewgibbons.co.uk/documents/mentoringdefinitions_000.doc, mentoring definitions.

Glasser, W. (1994). Dobra šola. Radovljica: Regionalni izobraževalni center.

Jarvis, P. (1995). Adult and continuing education: theory and practice. London,

New York: Routhledge.

Kejžar, I. (1986). Organizacija usposabljanja pripravnikov. Ljubljana: Zavod za tehnično izobraževanje.

Krajnc, A. (1979). Metode izobraževanja odraslih: andragoška didaktika. Ljubljana: Delavska enotnost.

Krajnc, A. (1984). Sodobni razvoj izobraževanja odraslih. Ljubljana: Zavod za tehnično izobraževanje. Kristančič, A. (1995). Svetovanje in komunikacija. Ljubljana: Združenje svetovalnih delavcev Slovenije.

Kristančič, A., Ostrman, A. (1998). Osnove in elementi svetovalne komunikacije. Ljubljana: AA Inserco svetovalna družba.

Lamovec, T. (1993). Spretnosti v medosebnih odnosih. Ljubljana: Center za psihodiagnostična sredstva. 
Littlejohn, S. W. (1992). Theories of human communication. Belmon: Wadsworth Publishing Company.

Nastran-Ule, M. (1994). Temelji socialne psihologije. Ljubljana: Znanstveno in publicistično središče.

Opalk, V. (2003). Vloga mentorja in podjetja pri strokovnih praksah: priročnik za usmerjanje mentorjev in vzpostavitev učinkovitega programa strokovne prakse v podjetju. Ljubljana: Pedagoški center Ekonomske fakultete.

Parsloe, E., Wray, M. J. (2000). Coaching and mentoring: practical methods to improve learning. London: Kogan Page.

Russell, J. E. A. (2004). »Mentoring«. V C. D. Spielberger (ur.), Encyclopedia of Applied Psychology, 2. Amsterdam.

Schulz, S. F. (1995). »The Benefits of mentoring «. V Galbraith, M. W., Cohen, N. H. (ur.), Mentoring: New Strategies and Challenges. San Francisco.

Zachary, L. J. (2000). The Mentor's Guide. San Francisco: Jossey-Bass.

Zachary, L. J. (2002). »The Role of Teacher as Mentor«. V Ross-Gordon, J. M. (ur.), Contemporary Viewpoints on Teaching Adults Effectively. San Francisco.

Zupan-Kušče, S. (1989). Mentor in pripravnik v združenem delu. Ljubljana: Skupnost izobraževalnih centrov v SR Sloveniji, Gospodarska zbornica Slovenije. 